\title{
A munkaerő-kölcsönzés hazai szabályozása az Európai Unió irányelveinek tükrében
}

\author{
munkaerö-kölcsönzés - szövetkezeti foglalkoztatás - egyenlö bánásmód - \\ határon átnyúló munkaerö-kölcsönzés - kiküldetés (posting)
}

2019 nyarán nagykorúságába lépett a munkaerő-kölcsönzés jogintézménye Magyarországon. 2001. július 1-jei bevezetése óta lényegesen változott a kölcsönzés jogi környezete, a jogfejlődés fő mérföldköveit a munkaerő-kölcsönzés keretében történő munkavégzésről szóló 2008/104/EK irányelv (a továbbiakban: irányelv) és a munka törvénykönyvéröl szóló 2012. évi I. törvény (a továbbiakban: Mt.) hatálybalépése jelentik. A közel két évtizedes gyakorlati tapasztalatok és számos törvénymódosítás után a munkaerö-kölcsönzés hazai szabályozását azonban máig nem tekinthetjük kiforrottnak, a jogintézményt több jogharmonizációs hiányosság, alkotmányos aggály és gyakorlati probléma is terheli. A jelen tanulmány célja a magyar munkaerő-kölcsönzés uniós jogi szempontú vizsgálata, azzal, hogy a jogharmonizációs problémák egyben számos tisztázandó belső jogi kérdésre is rávilágítanak. ${ }^{1}$

\section{A munkaerö-kölcsönzés fogalma, elhatárolása}

A munkaerő-kölcsönzés legfőbb sajátossága, hogy a hagyományos munkaviszonynyal szemben nem két, hanem három fél jogviszonyára épül. A munkavállaló egy munkaerő-kölcsönzéssel foglalkozó ügynökséggel, a kölcsönbeadóval köt munkaszerződést. Tényleges foglalkoztatására azonban mindig egy másik munkáltatónál, a kölcsönvevőnél kerül sor, akivel a kölcsönbeadó polgári jogi szerződést köt. E szerződés alapján a kölcsönbeadó egy bizonyos kölcsönzési díjért cserébe átengedi a munkavállalót a kölcsönvevőnek. A kikölcsönzés ideje alatt e megállapodás és

* Dr. Kártyás Gábor egyetemi adjunktus, Pázmány Péter Katolikus Egyetem, Jog- és Államtudományi Kar, Munkajogi Tanszék, kartyas.gabor@jak.ppke.hu.

1 Ezek szakirodalmi feldolgozása szinte egyidős magával a tételes szabályozással. A jelen tanulmányban elsősorban a szűkebb téma szempontjából jelentős forrásokra támaszkodtam, azokon belül is az újabb szakirodalomra helyezve a hangsúlyt. A munkaerö-kölcsönzés hazai szabályozásáról részletesen lásd küIönösen BANKó Zoltán: Az atipikus munkajogviszonyok. A munkajogviszony általánostól eltérö formái az Európai Unióban és Magyarországon. PhD-értekezés, Pécs, 2008; HoRvÁTH István: Hazai kölcsönzés - európai szemmel. A munkaerö-kölcsönzés magyar szabályozása - európai összehasonlításban, figyelemmel a 2008/104/EK irányelv jogharmonizációs követelményeire. Habilitációs értekezés, Budapest, 2013; FERENCZ Jácint: Az atipikus munkaviszonyok komplex megközelítése. Doktori értekezés, Györ, 2014; KÁRTYÁs Gábor: Munkaerö-kölcsönzés Magyarországon és az Európai Unióban. Wolters Kluwer, Budapest, 2015. 
a törvény ereje által a kölcsönvevő gyakorol bizonyos munkáltatói jogokat a munkavállaló felett, illetve őt terhelik egyes kötelezettségek is. A konstrukció lényege, hogy a kölcsönvevő úgy jut a munkaviszony sajátosságainak megfelelő alárendelt, utasítható munkaerőhöz, hogy neki magának nem kell munkaviszonyt létesítenie. Így mentesül a munkaviszonyhoz kötődő adminisztratív, közteher-fizetési kötelezettségek vagy a jogviszony létesítése/megszüntetése körüli jogi teendők, kockázatok alól. Ezt az elvi felépítést leképezve, a törvényi definíció szerint a munkaerö-kölcsönzés az a tevékenység, amelynek keretében a kölcsönbeadó a vele kölcsönzés céljából munkaviszonyban álló munkavállalót ellenérték fejében munkavégzésre a kölcsönvevőnek ideiglenesen átengedi. ${ }^{2}$

A Nemzeti Foglalkoztatási Szolgálat adatai szerint ${ }^{3}$ a munkaerő-kölcsönzés 20072018 közötti időszakra vonatkozó legfontosabb jellemzői az alábbiak.

1. táblázat. A munkaerő-kölcsönzés alakulása Magyarországon

\begin{tabular}{|l|r|r|r|r|}
\hline \multicolumn{1}{|c|}{ Mutató } & $\mathbf{2 0 0 7}$ & $\mathbf{2 0 1 2}$ & \multicolumn{1}{c|}{$\mathbf{2 0 1 5}$} & \multicolumn{1}{c|}{$\mathbf{2 0 1 8}$} \\
\hline Kölcsönbeadók száma & 796 & 867 & 880 & 866 \\
\hline Kölcsönvevők száma & 3829 & 8533 & 4786 & 6466 \\
\hline Munkavállalók száma & 99910 & 101485 & 124576 & 150172 \\
\hline
\end{tabular}

Forrás: saját szerkesztés a Nemzeti Foglalkoztatási Szolgálat adatai alapján

A közel ezer kölcsönbeadó cég összesen évente mintegy 100-150 000 munkavállalót foglalkoztat. A munkáltatóknak azonban csak egy töredéke, kb. 6-8000 szervezet vesz igénybe kölcsönzött munkaerőt, noha az érintett munkáltatók száma az elmúlt években jelentősen nőtt. A 2009-es gazdasági válság megtörte a kölcsönzés növekedési trendjét, miközben a 2015 után jelentőssé váló munkaerőhiány számottevően bővítette a szektort. Mindez nem magyar sajátosság. A nemzetközi kutatások rámutattak, hogy válság esetén a kölcsönzött munkavállalókat küldik el először a munkáltatók, ám a helyzet jobbra fordulásával őket veszik fel először. ${ }^{4} A$ hazai adatok szerint a kölcsönzött munkavállalók mintegy 45\%-a legfeljebb általános iskolai végzettséggel rendelkezik, kétharmaduk a feldolgozóiparban dolgozik.

\subsection{Elhatárolási kérdések: a szövetkezeti foglalkoztatás}

A munkaerő-kölcsönzéshez nagyon hasonló foglalkoztatási forma valósul meg bizonyos szövetkezeteken keresztüli munkavégzésnél, ami jogharmonizációs kérdéseket vet fel. A szövetkezetek egyes típusai ugyanis kifejezetten abból a célból hozhatók

2 Mt. 214. § (1) bekezdés a) pont.

3 Lásd https://nfsz.munka.hu/Lapok/full_afsz_kozos_statisztika/stat_osszefogl_munkaero-kolcson_tevekeny. aspx (2019. 10. 07.).

4 ILO: Private employment agencies, temporary agency workers and their contribution to the labour market. Issues paper for discussion at the Workshop to promote ratification of the Private Employment Agencies Convention, 1997 (No. 181), 20-21 October 2009. International Labour Office, Sectoral Activities Programme, Genf, 2009, 26-31. 
létre, hogy tagjaiknak - tipikusan nehezen foglalkoztatható csoportoknak, például tanulmányokat folytatóknak, nyugdíjasoknak, álláskeresőknek - munkalehetőségeket szervezzenek. Ide tartozik a szociális, az iskola- és a közérdekű nyugdijas szövetkezet. A szociális szövetkezet közvetlenül maga szervezi a munkát, a tagok a szövetkezet infrastruktúráját (üzemét) használva dolgoznak. Az iskolaszövetkezetben és a közérdekű nyugdíjas szövetkezetben viszont a szövetkezeti törvény kifejezetten megengedi, hogy a munkavégzés harmadik személy részére történő szolgáltatás keretében történjen. Az iskola- és nyugdíjas szövetkezetek általában egy harmadik félnek engedik át tagjaik munkaerejét, amelyért e harmadik fél a szövetkezetnek dijazást fizet. E harmadik fél szempontjából tehát tartalmilag a munkaerö-kölcsönzéssel egyező szolgáltatás valósul meg. ${ }^{5}$ Például, az iskolaszövetkezet ellenértékért cserébe tagjait rendelkezésre bocsátja egy gyorsétterem részére. Ez megfelel a kölcsönzési irányelv definíciójának, hiszen a szövetkezet a szolgáltatás fogadójának felügyelete és irányítása melletti ideiglenes munkavégzésre engedi át tagjait. ${ }^{6}$ Noha a szövetkezet és a tag között munkaviszony formálisan nem áll fenn, a jogviszonyok rendeltetése és tartalma szerint komolyan felmerülhet annak a lehetősége, hogy ezt a jogviszonyt egy bíróság munkaviszonynak minősítse, a felek (és a jogalkotó) akarata ellenére. ${ }^{7}$

Döntő különbség a munkaerö-kölcsönzéshez képest, hogy a szövetkezetekben a munkavégzés nem munkaviszonyban történik. Míg a kölcsönzött munkavállaló munkaviszonyban áll a kölcsönbeadóval, addig a szövetkezet tagjai kétféle jogviszony keretében dolgoznak. Az iskola- és nyugdíjas szövetkezeteknél a tag „sajátos jogviszonyban” áll, míg a szociális szövetkezetben „tagi munkavégzés” valósul meg.

A „sajátos jogviszony” nem minősül munkaviszonynak, amire csak néhány munkajogi elöírást kell alkalmazni, amelyeket a szövetkezeti törvény felsorol. Ezek az alábbiak: munkaközi szünet, napi pihenőidő, minimálbér, a 18. életévét be nem töltött tag esetén a fiatal munkavállalóra vonatkozó rendelkezések és a munkavédelmi szabályok. ${ }^{8} \mathrm{Ha}$ a tagot a szolgáltatás fogadója részére történő munkavégzés során kár éri, azért a szövetkezet és a szolgáltatás fogadója egyetemlegesen felel. Ám ez a Ptk. szerinti kárfelelősséget, és nem az Mt. szerinti munkáltatói kárfelelősséget jelenti. ${ }^{9} \mathrm{Az}$ Mt. összes többi munkajogi szabálya nem alkalmazható e munkát végzőkre. Így például nem korlátozott a napi és heti munkaidő mértéke, nincs fizetett szabadság, betegszabadság, a jogviszony pedig bármiféle garancia (felmondási idő, indokolási kötelezettség stb.) nélkül megszüntethető. Mindez azért aggályos, mert foglalkoztatói oldalról viszont a szolgáltatás fogadóját ugyanolyan tartalmú, széles körű utasítási jog illeti meg, mint a munkáltatót a munkaviszonyban. A törvény szerint ugyanis az utasításadási jog kiterjed a feladatteljesítés módjának, idejének és ütemezésének meghatározására is. ${ }^{10}$

5 Részletesen lásd a szövetkezetekröl szóló 2006. évi X. törvény 10/B-11., 18. és 29. §-át.

6 Irányelv 3. cikk (1); HoRVÁTH István: Ideiglenesen tartózkodók. A munkaerö-kölcsönzés: uniós követelmények, magyar megoldások. In: Horváth István (szerk.): Tisztelgés. Ünnepi tanulmányok Dr. Hágelmayer Istvánné születésnapjára. ELTE Eötvös Kiadó, Budapest, 2015, 171.

7 SIPKA Péter-ZACCARIA Márton Leó: A szövetkezeti tagi munkaviszony jogi kockázatai, különös tekintettel az alapvető munkavállalói jogokra. Munkajog, 2017/1, 25.

8 A munkavédelemröl szóló 1993. évi XCIII. törvény (a továbbiakban: Mvt.) 87. § 9. pontja.

9 2006. évi X. törvény 10/B-11. § és 29. §.

10 2006. évi X. törvény 10/B. § (3) és 29. § (3). 
Ettől eltérően a szociális szövetkezeteknél úgynevezett tagi munkavégzés valósul meg. A szövetkezeti törvény szerint ez „más munkavégzésre irányuló jogviszonyt szabályozó törvény hatálya alá nem tartozó jogviszony”. Erre sem az Mt., sem a polgári jog szabályai nem irányadóak, még csak részleteikben sem. Ez a foglalkoztatási forma tehát - példátlanul a magyar jogrendszerben - semmiféle munkajogi szabály hatálya alatt nem áll (egyedül a munkavédelmi törvény terjed ki rá). A munkajogi védettség legalapvetőbb, alkotmányos vagy nemzetközi egyezményekből eredő alapjait sem biztosító tagi munkavégzés jogi nonszensz, amelyre a szakirodalom már részletesen felhívta a figyelmet. ${ }^{11}$ Ezt a teljes kiszolgáltatottságot nyilvánvalóan semmilyen foglalkoztatáspolitikai cél nem indokolja, legyenek az érintett tagok akármennyire hátrányos helyzetben a munkaerőpiacon. ${ }^{12}$ Ezt már csak azért sem lehetne az érintett csoportok foglalkoztatásának támogatásával indokolni, mert a kedvezményes szabályok nem a munkát végző személyéhez, hanem a speciális munkáltatóhoz (a szövetkezethez) kötődnek. Azaz, ha ugyanazt a nyugdíjas vagy tanulmányokat folytató személyt más munkáltató alkalmazza, akkor azt csak az Mt. általános szabályai alapján teheti meg.

Mindemellett a bemutatott munkavégzési formák nem járnak biztosítási jogviszonynyal, így nem kell megfizetni a társadalombiztosítási járulékokat, sem a szociális hozzájárulási adót. ${ }^{13}$ Így a tagi munkavégzés keretében vagy a nyugdíjas, illetve iskolaszövetkezeti tagok közreműködésével ellátható feladatok után jóval alacsonyabb a fizetendő közteher is.

A szövetkezeti foglalkoztatás fenti modelljét e helyütt részletesen csak az uniós jognak való megfelelés szempontjából vizsgálom. Az Európai Bíróság Ruhrlandklinikügyben hozott ítélete ${ }^{14}$ szerint ugyanis a munkaerő-kölcsönzési irányelvet akkor is alkalmazni kell, ha a ténylegesen kölcsönzési szolgáltatás keretében átengedett személy nem munkavállaló a nemzeti jog alapján, de a munkavégzésére tekintettel védelemben részesül. Ez az értelmezés kifejezetten aktuálissá teszi a hazai iskolaés nyugdíjas szövetkezeteken keresztüli foglalkoztatás felülvizsgálatát.

Az ügy tényállása szerint egy német ápolónő egy nonprofit egyesületnél dolgozott, amely a Német Vöröskereszt ápolónői közösségeinek szövetségéhez tartozott. Az egyesülettel nem kötött munkaszerződést. Munkavégzése az egyesületi tagságán alapult, és azon az ebből eredő kötelezettségén, hogy az egyesület részére személyes alárendeltségi viszonyban végzett szolgáltatást nyújt. Erre nem közvet-

11 A szövetkezeti tagi személyes közremüködés munkajogi kidolgozatlanságát már régóta aggályosnak tartja a szakirodalom. Lásd KendeRES György-PRugBERGER Tamás: Hozzászólás a munkaerő-kölcsönzés időszerü elméleti és gyakorlati problémáihoz. Magyar Jog, 2007/1, 39. A hatályos szabályozás kritikájához lásd FERENCZ: i. m., 161.; LóRÓDI László: A munkaviszonyon túli foglalkoztatási viszonyok. Szociális szövetkezet, tagi munkavégzési jogviszony. HR-Munkajog, 2014/11-12.; SIPKA-ZACCARIA: i. m.

12 A visszaélésekre a Szociális Szövetkezetek Országos Szövetsége is felhívta a figyelmet állásfoglalásában. Állásfoglalás a gazdasági társaságok számára szociális szövetkezetek részéről felajánlott tagi munkavégzésről, Budapest, 2014. 08. 24. http://www.szoszov.hu/allasfoglalas-a-gazdasagi-tarsasagok-szamaraszocialis-szovetkezetek-reszerol-felajanlott-tagi (2019. 10. 07.).

13 A társadalombiztosítás ellátásaira és a magánnyugdíjra jogosultakról, valamint e szolgáltatások fedezetéről szóló 1997. évi LXXX. törvény 5. § (1) bekezdés b) pont, a szociális hozzájárulási adóról szóló 2018. évi LII. törvény 5 . $\S(1)$ bekezdés $c)$, d) és $f$ ) pontok.

14 C-216/15. sz., Betriebsrat der Ruhrlandklinik GmbH és Ruhrlandklinik GmbH ügyben 2016. november 17-én hozott ítélet (ECLI:EU:C:2016:883). 
lenül az egyesületnél, hanem egy kórháznál került sor, ahová az egyesület munkaerő-kölcsönzési megállapodás alapján küldte ki dolgozni. A kórház ezért cserébe az egyesületnek díjat fizetett, ami munkaerőköltséget és 3\% kezelési díjat tartalmazott. A vita az ápolónőt kikölcsönző kórház és a helyi üzemi tanács között alakult ki. Utóbbi szerint ugyanis ez a foglalkoztatás munkaerő-kölcsönzésnek minősült, márpedig az üzemi tanács az ápolónő tartós kikölcsönzéséhez nem járult hozzá. A munkáltató ezt vitatta, és álláspontja szerint az ápolónő nem volt kölcsönzött munkavállaló. A német bíróság végül az Európai Bírósághoz fordult azzal a kérdéssel, hogy a munkaerő-kölcsönzésről szóló irányelv alapján a szóban forgó személyt kölcsönzött munkavállalónak kell-e tekinteni.

A „munkavállaló” a kölcsönzési irányelv értelmében olyan személy, akit az adott tagállamban a nemzeti munkajog munkavállalóként véd. ${ }^{15}$ Ebből az Európai Bíróság arra a következtetésre jutott, hogy a tagállamok nem dönthetik el teljesen szabadon, hogy kit tekintenek az irányelv hatálya alá eső munkavállalónak. Ezzel szemben az ítélet szerint a „munkavállaló” fogalma alá tartozik valamennyi olyan személy, aki munkát végez, és aki ezen a jogcímen az adott tagállamban védelemben részesül. Emellett az irányelv szerint a kölcsönzött munkavállalónak nem kell szükségszerüen munkaszerződést kötnie a kölcsönbeadóval, hanem elegendő, ha azzal munkaviszonyban áll. Ezért az Európai Bíróság nem tulajdonított jelentőséget annak, hogy a német jog alapján a szóban forgó ápolónő és a szövetség között nem volt munkaszerződés. Az Európai Bíróság ítélkezési gyakorlata alapján a munkaviszony alapvető jellemzője az a körülmény, hogy valamely személy meghatározott ideig, más javára és más irányítása alatt, díjazás ellenében szolgáltatást nyújt. ${ }^{16} \mathrm{Ha}$ ezek a feltételek fennállnak, akkor a szóban forgó személy munkavállalónak minősül.

Miközben tehát a munkavállaló fogalmának meghatározása nemzeti hatáskör, az Európai Bíróság értelmezésében a kölcsönzési irányelv maga megadja e fogalom körvonalait, amelyeket a tagállamoknak követniük kell. Ezért a kölcsönzési irányelvet minden olyan személyre alkalmazni kell, aki - a fenti jellemzők alapján - munkaviszonnyal rendelkezik, és aki az adott tagállamban az általa végzett munka alapján védelemben részesül. A munkavállaló fogalmának ilyen kiterjesztő értelmezését az ítélet azzal is alátámasztja, hogy máskülönben a tagállamok könnyen kiüresíthetnék az irányelv hatályát, amely így nem tudná célját betölteni. Ehhez nem kellene mást tenni, mint külön jogi státuszt meghatározni olyan személyekre, akik egyébként a kölcsönzött munkavállalókhoz teljesen hasonló jogviszonyban dolgoznak. A konkrét esetben az Európai Bíróság megállapította, hogy az ápolónő jogviszonyára számos munkajogi szabály hatálya kiterjed (például fizetett szabadság, betegszabadság, indokoláshoz kötött jogviszony-megszüntetés). Ez alapján valószínúnek látszik a következtetés, hogy az irányelv hatálya alá eső személyről van szó. Mindazonáltal az Európai Bíróság nem mondta ki a végső szót, hanem a nemzeti bírósághoz utalta vissza annak pontos mérlegelését, hogy a fenti szempontok alapján a szóban forgó személy munkavállalónak minősül-e.

15 Irányelv 3. cikk (1) bekezdés a) pont.

16 Az újabb gyakorlatban lásd C-518/15. sz., Ville de Nivelles kontra Rudy Matzak ügyben 2018. február 21-én hozott ítélet (ECLI:EU:C:2018:82), 28-29. pont; C-216/15. sz., Ruhrlandklinik-ügyben hozott ítélet, 27. pont. 
A hazai jog szempontjából nézve az iskolaszövetkezeti és a közérdekủ nyugdijas szövetkezeti foglalkoztatás esetében is igaz, hogy a munkát végző a szövetkezeti tagsági jogviszonya alapján, személyes közremüködés keretében dolgozik, ami megvalósulhat harmadik személy részére nyújtott szolgáltatás keretében is (illetve tipikusan így valósul meg), amelyért a szövetkezet ellenértékben részesül. E körben a szolgáltatás fogadója kifejezetten jogosult utasítást adni, ami kiterjed a feladatteljesítés módjának, idejének és ütemezésének meghatározására. Erre a gyakorlatilag alárendelt - munkavállaló-szerủ - státuszra tekintettel pedig egyes munkajogi szabályokat e foglalkoztatási formára is alkalmazni kell, tehát e munkát végzőket a magyar munkajog védelemben részesíti.

Az ítélet gondolatmenetét követve e személyek aligha vonhatóak ki a kölcsönzési irányelv hatálya alól. Ha viszont ez így van, akkor az abban foglalt garanciákat rájuk is alkalmazni kell. Így különösen, legalább olyan bánásmódra jogosultak a munkaidő (köztük a szabadság) és a munka díjazása vonatkozásában, mint amit a szolgáltatás fogadója a közvetlenül alkalmazott munkavállalóinak biztosít. ${ }^{17}$ Ez a következtetés persze jelentősen átformálná e szövetkezetek jelenlegi foglalkoztatási gyakorlatát.

Meglátásom szerint az Európai Bíróság ítélete fontos problémára irányítja rá a figyelmet. Az egész munkajogi szabályozás logikáját kikezdő és kerülendő tendencia, ha mesterségesen kreált státuszokkal kiüresítjük a munkavállaló fogalmát, és így vonunk ki egyeseket a munkajogi szabályok védőernyője alól. Az pedig kifejezetten aggályos, ha szociális célzattal és a hátrányos helyzetű személyeken történő segítség szándékával megfogalmazott jogszabályi rendelkezésekböl talán éppen a szociális szempontok hiányoznak. ${ }^{18}$ Véleményem szerint ezért az uniós jogi megfelelésen túlmutató okokból is mindenképpen szükséges a szövetkezeti foglalkoztatás reformja, és visszaemelése a munkajog védőernyője alá.

\section{A határon átnyúló munkaerő-kölcsönzés}

A határon átnyúló munkaerö-kölcsönzés a magyar munkajog igazi „mostohagyermeke". A kölcsönzés e tényállása ugyanis - megannyi korrekció ellenére - makacsul szembemegy az uniós jog egyik gazdasági alapszabadságával, a szolgáltatásnyújtás szabadságával.

Kölcsönbeadó nem lehet minden munkáltató, csak amelyik eleget tesz az erre vonatkozó külön jogszabályi feltételeknek. Ezeket az Mt. mellett a munkaerö-kölcsönzési és a magán-munkaközvetítői tevékenység nyilvántartásba vételéröl és folytatásának feltételeiről szóló 118/2001. (VI. 30.) Korm. rendelet (a továbbiakban: Kr.) határozza meg. A kölcsönzési tevékenység hazai feltételei, hogy csak az állami foglalkoztatási szerv (kormányhivatal) általi nyilvántartásba vétel után folytatható, 10 millió forint vagyoni letét nyújtása, továbbá megfelelő személyi és tárgyi feltételek biztosítása esetén. ${ }^{19}$

17 Irányelv 5. cikk.

18 SIPKA-ZACCARIA: i. m., 30.

19 Kr. 4. § (1). 
Az első probléma az volt, hogy 2001. július 1-jétől, a munkaerő-kölcsönzés hazai bevezetésétől kezdve munkaerő-kölcsönzési tevékenységet csak belföldi székhelyü kölcsönbeadók végezhettek. ${ }^{20}$ Mintegy kilenc évvel később a Rani-ügyben az Európai Bíróság - a szolgáltatásnyújtás szabadságának durva megsértése miatt megállapította e rendelkezés uniós jogba ütközését, ${ }^{21}$ a szabályozás módosítására mégis csak újabb közel másfél évvel később került sor. ${ }^{22}$

A Rani-ügyben a Fővárosi Bíróság azzal az előzetes döntéshozatali kérelemmel fordult a Bírósághoz, hogy a belföldi székhelyet előíró magyar szabály összhangban volt-e az uniós joggal. Az ügy tényállása szerint egy magyar munkáltató egy szlovákiai székhelyű kölcsönbeadótól vett igénybe kölcsönzött munkaerőt. A felek között jogvita keletkezett a kölcsönzési szerződés teljesítése kapcsán, amelyben az alperes kölcsönvevő arra hivatkozott, hogy mivel a felperesnek nincsen belföldi székhelye Magyarországon, ezért a kölcsönzési szerződés semmis. A magyar Kormány nem próbált olyan közérdeket felmutatni, amely indokolná a belföldi székhely előírását. Ehelyett arra hivatkozott az eljárás során, hogy a vitatott szabály nem is vonatkozik a külföldi kölcsönbeadókra, ${ }^{23}$ és ezt az értelmezést követi a hatóságok joggyakorlata is. Az Európai Bíróság ezt az érvelést nem fogadta el. Mint rámutatott, az egyszerü közigazgatási gyakorlatot - amely jellegénél fogva az eljáró szervek belátása szerint módosítható és nem is kellően nyilvános - nem lehet az uniós jogban előírt kötelezettségek érvényes végrehajtásának tekinteni. Egyébként pedig megerősítette azt a korábbi, következetes gyakorlatát, amely szerint a munkavállalók védelme céljához képest aránytalan korlátozásnak minősül a belföldi székhely előírása. ${ }^{24}$

2011. december 1-je óta tehát a kölcsönbeadó nemcsak belföldi, hanem bármely EGT-államban székhellyel rendelkező vállalkozás lehet, amely a rá irányadó jog szerint munkaerő-kölcsönzést folytathat, feltéve, hogy egyben megfelel a munkaerö-kölcsönzés hazai feltételeinek is. ${ }^{25}$ Ezzel egyezően az Mt. a kiküldetés szabályai kapcsán úgy rendelkezik, hogy a munkaerő-kölcsönzés valamennyi szabálya alkalmazandó a kiküldött munkavállalóra. ${ }^{26}$

20 A Munka Törvénykönyvéröl szóló 1992. évi XXII. törvény (a továbbiakban: 1992. évi Mt.) 193/D. § (1).

21 C-298/09. sz., RANI Slovakia s. r. o. kontra Hankook Tire Magyarország Kft. ügyben 2010. június 16-án hozott végzés (ECLI:EU:C:2010:343).

22 Az új szabályokat az egyes munkaügyi tárgyú és más kapcsolódó törvények jogharmonizációs célú módosításáról szóló 2011. évi CV. törvény tartalmazta, hatályos 2011. december 1-jétől.

23 Ez egyébként nem volt egyértelmü, figyelemmel arra, hogy az 1992. évi Mt. 1. § (1) bekezdése minden magyarországi munkavégzést a hatálya alá vont, kivéve, ha a nemzetközi magánjogi szabályok eltérően rendelkeztek. A Rendelet kapcsolódó szabályai (a rendszeres munkavégzés helye, az alkalmazó telephely, illetve a legszorosabban kapcsolódó jog) azonban könnyedén vezethettek a magyar munkajog alkalmazásához. Sőt, volt olyan kúriai ügy, amelynek tényállásából világos, hogy a munkaügyi hatóság még a Raniügyben hozott döntés után is számonkérte a más tagállambeli kölcsönbeadókon a belföldi székhely hiányát. Lásd: Mfv.III.10.003/2017/5. [3].

24 C-298/09. sz., Rani-ügyben hozott végzés, 29., 56. pont.

25 Mt. 215. § (1); a munkaerő-kölcsönzési és a magán-munkaközvetítői tevékenység nyilvántartásba vételéröl és folytatásának feltételeiről szóló 118/2001. (VI. 30.) Korm. rendelet (a továbbiakban: Kr.) 3. § (2), 17/E. §. Ez egyben azt is jelenti, hogy az EGT-államokon kívüli, más államban letelepedett kölcsönbeadó Magyarországra nem nyújthat szolgáltatást (TAKÁcs Gábor: A munkaerö-kölcsönzés. Az iskolaszövetkezeti munkaviszony. In: GYULAVÁRI Tamás-Hős Nikolett-KÁRTYÁs Gábor-TAKÁcs Gábor: A Munka Törvénykönyve 2012. Egységes szerkezetben állásfoglalásokkal és magyarázatokkal. Kompkonzult Kiadó, Budapest, 2012, 293.).

26 Mt. 295. § (1) bekezdés d) pont, 214-222. §. 
Kétséges ugyanakkor, hogy az irányelv felhatalmazást ad-e egy tagállamnak, hogy a kölcsönzött munkavállalót védő garanciák mellett a kölcsönbeadói tevékenység végzésére vonatkozó előírásait - például az engedélyezési kötelezettséget is kiterjessze a más tagállamban letelepedett és a területére munkavállalókat kölcsönző kölcsönbeadókra. Álláspontom szerint erről nyilvánvalóan nem lehet szó; a kölcsönbeadói tevékenység hatósági bejegyzésére, engedélyezésére vagy felügyeletére vonatkozó tagállami rendelkezések csak akkor terjeszthetőek ki a más tagállambeli kölcsönbeadókra, ha az megfelel az elsődleges jog követelményeinek is. E szempontból viszont a hatályos szabályozás kifogásolható.

E feltételek egyebek mellett előírják, hogy Magyarországon munkaerő-kölcsönzés csak az állami foglalkoztatási szerv általi nyilvántartásba vétel után folytatható. A Kr. szerint a nyilvántartásba vételt a leendő kölcsönbeadó székhelye szerinti kormányhivatal intézi. Sajnálatos hiba, hogy egészen 2016. december 1-jéig a jogszabály nem tért ki arra, melyik szerv lesz illetékes a belföldön székhellyel nem rendelkező, külföldi kölcsönbeadók esetén. Így bár 2011. augusztus 1-je óta a más tagállambeli szolgáltató is kölcsönözhetett Magyarországra, a nyilvántartásba vétel - és ezáltal a legális tevékenység - a gyakorlatban még további, több mint öt évig lehetetlen volt. Noha 2016 decemberétől ez az akadály elhárult, ${ }^{27}$ a részletszabályok továbbra sincsenek tekintettel a szolgáltatásnyújtás szabadságára, különösen a duplikáció tilalmára. ${ }^{28}$

Egyrészt a nyilvántartásba vétel feltétele, hogy a kérelmező 10 millió forint vagyoni biztosíték letétbe helyezését igazolja. ${ }^{29} \mathrm{~A} \mathrm{Kr}$. kifejezetten előírja, hogy a vagyoni biztosítékra vonatkozó szabályait a székhely szerinti állam által a kölcsönzési tevékenységre előírt vagyoni biztosítéktól függetlenül kell teljesíteni, azzal, hogy a biztosíték külföldi pénzügyi intézménynél is leköthető. ${ }^{30} \mathrm{Ez}$ a rendelkezés nyilvánvalóan szemben áll az Európai Bíróság gyakorlatával, hiszen ha a vagyoni letét funkciója már a kiküldő tagállamban megvalósul, akkor az nem írható elő újra a fogadó államban. ${ }^{31}$ Ehhez képest csak azt lehet megkövetelni, hogy ha a kiküldő állam joga alacsonyabb vagyoni letétet ír elő, akkor azt a magyarországi nyilvántartásba vételhez ki kell egészíteni 10 millió forintra.

Hasonlóan aggályos az a követelmény, amely szerint a leendő kölcsönbeadónak a tevékenység gyakorlásához megfelelő, vezetékes telefonvonallal ellátott irodahelyiséggel kell rendelkeznie, mégpedig Magyarország területén. ${ }^{32} \mathrm{~A}$ szabályt igazoló közérdek a kölcsönzött munkavállalók védelme lehet, közelebbről, hogy a

27 Külföldi kérelmező esetén az eljárást Budapest Főváros Kormányhivatala folytatja le. Kr. 17/F. § (1).

28 Szintén a szolgáltatásnyújtás szabadsága szempontjából kifogásolja a szabályozást: BERKE Gyula-KISS György: Kommentár a munka törvénykönyvéhez. A munka törvénykönyve magyarázata. Budapest, Complex Kiadó, 2012, 522.

29 Kr. 6. § (2)-(3).

$30 \mathrm{Kr} .17 / \mathrm{F} . \S(6)$.

31 Lásd C-279/80. sz., Alfred John Webb-ügyben 1981. december 17-én hozott ítélet (ECLI:EU:C:1981:314); C-43/93. sz., Raymond Vander Elst-ügyben, 1994. augusztus 9-én hozott ítélet (ECLI:EU:C:1994:310); kifejezetten a kölcsönbeadók vagyoni letétje kapcsán: C-279/00. sz., Bizottság vs. Olaszország ügyben 2002. február 7-én hozott ítélet (ECLI:EU:C:2002:89).

32 Kr. 5. § (2), 17/F. § (3). 
más tagállambeli kölcsönzöttek a magyarországi munkavégzésük ideje alatt is elérhessék kölcsönbeadójukat egy belföldi irodában. Rá kell mutatni azonban, hogy ez az előírás aligha jelent tényleges előnyt ${ }^{33}$ a munkavállalóknak. Hiába érhető el a kölcsönbeadó mobiltelefonon, faxon, interneten, mobilalkalmazáson stb. keresztül, nem vehető nyilvántartásba, ha nincs legalább egy vezetékes telefonja is, amely egy belföldi irodában csörög. Márpedig az uniós jog alapján nem lehetne megtagadni a bejegyzés iránti kérelmet, ha a munkavállalókkal való kapcsolattartás egyéb eszközökkel már biztosított. Másfelöl, egy nemritkán százas nagyságrendű munkavállalói állománnyal dolgozó szervezet számára egyetlen vezetékes telefonvonal nyilvánvalóan kevés. Végül, a munkavállalót érintően olyan adminisztratív teendők, amelyek a kölcsönbeadó fizikai jelenlétét kívánják meg, döntően a munkaviszony létesítése és megszüntetése kapcsán jelentkeznek, amelyek a kiküldő államban, és nem a kikölcsönzés helyén teljesítendőek. Ezért a belföldi iroda megkövetelése megítélésem szerint a cél elérésére alkalmatlan korlátozás, akkor is, ha egyébként a magyar jogszabály az iroda használatának igazolására bármilyen jogcímet elfogad (például a szívességi használatot is).

Összességében, a határon átnyúló munkaerő-kölcsönzés hazai szabályozása egy előzetes döntéshozatali ügy és több jogszabály-módosítás után sem felel meg az uniós kereteknek. A más tagállambeli kölcsönbeadóval szemben elöírt adminisztratív követelmények ellentétesek az uniós joggal.

\section{A kölcsönbeadó és a kölcsönvevő közötti jogviszony}

A kölcsönzött munkavállalók átengedéséröl a kölcsönbeadó és a kölcsönvevő egy polgári jogi szerződést kötnek, amelyre a munkajog csak néhány alapvető előírást tartalmaz, de egyébként a polgári jog szabályai alkalmazandóak rá. Így a legtöbb kérdésben a kölcsönbeadó és a kölcsönvevő maguk dönthetnek. A szerződésröl a törvény mindössze annyit rögzít, hogy az csak írásban érvényes, kötelezően tartalmazza a kölcsönzés lényeges feltételeit és a munkáltatói jogkör gyakorlása megosztását. ${ }^{34} \mathrm{~A}$ lényeges feltételek meghatározása (például a kikölcsönzés időtartama, a munkavégzés helye, a kölcsönzési díj) azonban már teljesen a felek megállapodására bízott kérdés.

A munkaerö-kölcsönzés foglalkoztatáspolitikai szerepének erősítésére a törvény szerint érvénytelen a megállapodás, amely a munkaviszony megszűnését vagy megszüntetését követően a kölcsönvevővel való jogviszony létesítési tilalmat vagy korlátozást ír elö. ${ }^{35}$ Nincs azonban akadálya olyan kikötésnek, amely szerint a kölcsönvevő csak ellenérték fejében veheti saját alkalmazásba a hozzá kikölcsönzött munkavállalót. Az uniós irányelv ehhez azonban azt is megköveteli, hogy az átvételi

33 Lásd ehhez az alábbi eseteket: C-369-376/96. sz., Jean-Claude Arblade és Arblade \& Fils SARL ügyben 1999. november 23-án hozott ítélet (ECLI:EU:C:1999:575); C-165/98. sz., André Mazzoleni és Inter Surveillance Assistance SARL ügyben 2001. március 15-én hozott ítélet (ECLI:EU:C:2001:162); C-164/99. sz., Portugaia Construções $L d^{a}$ ügyben 2002. január 24-én hozott ítélet (ECLI:EU:C:2002:40).

34 Mt. 217. §(1).

35 Mt. 216. § (3) bekezdés a) pont. 
díj „észszerü mértékü” legyen. ${ }^{36}$ Ez a követelmény legfeljebb közvetve vezethető le a magyar szabályból, miszerint az észszerütlen mértékü ellenérték már az átvétel ellehetetlenítését jelentené. Kétséges, hogy ezt elfogadná-e a Bizottság az irányelv megfelelő átvételének.

\subsection{Az ideiglenességi szabály}

A munkaerő-kölcsönzés egyik alapvető jellemzője világszerte, hogy a munkavállaló csak egy bizonyos időtartamot dolgozhat ugyanannál a kölcsönvevőnél. Ezzel a munkajog azt kívánja megakadályozni, hogy a munkáltatók a tartós foglalkoztatást is kölcsönzéssel váltsák ki. Ilyen időbeli korlátot a magyar munkajog 2011 végéig nem ismert. A kikölcsönzések ideiglenességét azonban a kölcsönzési irányelv előírta, ${ }^{37}$ ezért kérdéses volt, hogyan alakítja majd át a hazai gyakorlatot, ha a kölcsönzött munkavállaló Magyarországon is csak ideiglenesen állhat egy-egy kölcsönvevő foglalkoztatásában.

A jogalkotó végül rendkívül tágan (a határozott idejü munkaviszonyhoz hasonlóan) ${ }^{38}$ öt évben határozta meg az egy kölcsönvevőnél eltölthető maximális időtartamot. ${ }^{39}$ Ezt a mértéket vette át az Mt. is. ${ }^{40}$ Hozzá kell tenni, hogy a Nemzeti Foglalkoztatási Szolgálat statisztikái ${ }^{41}$ szerint a hazai gyakorlatban a kikölcsönzések az ötéves korláthoz képest sokkal rövidebbek, ritkán haladják meg a 3-4 hónapot (lásd a 2. táblázatban). Így csak kivételesen fordulhat elő, hogy egy kölcsönvevő az ötéves korlát miatt kénytelen megszüntetni egy munkavállaló további foglalkoztatását. Ha ez lenne a helyzet, úgy megoldás lehet, hogy a kölcsönvevő maga létesít munkaviszonyt a kölcsönzött munkavállalóval. Mindenesetre sajnálatos, hogy az Mt. hatálybalépése óta nem publikálnak adatokat a kikölcsönzések hosszának alakulásáról.

2. táblázat. A kikölcsönzési esetek átlagos hossza Magyarországon (2005-2010)

\begin{tabular}{|l|c|c|c|c|c|c|}
\hline \multirow{2}{*}{\multicolumn{1}{|c|}{ Állománycsoport }} & \multicolumn{5}{|c|}{ A kikölcsönzési esetek átlagos } \\
hossza (nap) \\
\cline { 2 - 8 } & $\mathbf{2 0 0 5}$ & $\mathbf{2 0 0 6}$ & $\mathbf{2 0 0 7}$ & $\mathbf{2 0 0 8}$ & $\mathbf{2 0 0 9}$ & $\mathbf{2 0 1 0}$ \\
\hline Fizikai munkakörben dolgozók & 85 & 123 & 89 & 88 & 44 & 40 \\
\hline Szellemi munkakörben dolgozók & 122 & 183 & 129 & 120 & 94 & 73 \\
\hline
\end{tabular}

36 Irányelv 6. cikk (2).

37 Lásd a fogalommeghatározásokat az irányelv 3. cikk (1) bekezdésében.

38 Mt. 192. §.

39 Bevezette a 2011. évi CV. törvény. HoRvÁTH István: Rugalmasabb biztonság. A munkaerő-kölcsönzés hazai szabályai - elsődleges figyelemmel az Európai Unió meghatározó jogközelítési normáira. Munkajog, 2019/03, 12.

40 Mt. 214. § (2).

41 Lásd: https://nfsz.munka.hu/Lapok/full_afsz_kozos_statisztika/stat_osszefogl_munkaero-kolcson_tevekeny. aspx (2019. 10. 07.). 


\begin{tabular}{|l|c|c|c|c|c|c|}
\hline \multirow{2}{*}{\multicolumn{1}{|c|}{ Állománycsoport }} & \multicolumn{5}{c|}{ A kikölcsönzési esetek átlagos } \\
hossza (nap)
\end{tabular}

Forrás: saját szerkesztés a Nemzeti Foglalkoztatási Szolgálat adatai alapján

Az ötéves korlátot túllépve a munkavállalót az adott kölcsönvevőnél nem lehet tovább foglalkoztatni. ${ }^{42}$ Ilyen esetben a munkavállaló - mint jogellenes utasítást megtagadhatja a kölcsönvevőnél való további munkavégzést, a munkaügyi hatóság pedig a munkaerő-kölcsönzés szabályainak megszegése miatt bírságot szabhat ki. ${ }^{43}$ Bár az Mt. kifejezetten nem tartalmazza, hogy ilyenkor a kölcsönvevővel jön létre határozatlan idejü munkaviszony, a munkaügyi hatóság az ellenőrzés során megállapított tényállás alapján minősítheti így a ténylegesen létrejött kapcsolatot. ${ }^{44}$ Az ötéves időkorlát túllépésével ugyanis munkaerő-kölcsönzés keretében a kölcsönvevő nem foglalkoztathatja a munkavállalót, viszont minden, a tényleges munkavégzéshez kötődő munkáltatói jogkört ő gyakorol. Megítélésem szerint erre a szigorúbb értelmezésre mindenképpen szükség lenne, hogy a hossza miatt amúgy is súlytalan ideiglenességi szabály némi jelentőséget kapjon.

\subsection{Tilalmak és korlátozások}

Az irányelv 4. cikke alapján a korlátozásokat és tilalmakat a jogharmonizáció során felül kellett vizsgálni, és csak akkor voltak fenntarthatóak, ha általános érdeket szolgálnak. Az Európai Bíróság az AKT-ügyben ${ }^{45}$ igen puha értelmezést adott e cikknek. Megállapította, hogy a 4. cikk címzettjei kizárólag a tagállamok hatáskörrel rendelkező hatóságai, és nem a bíróságok. A korlátozások áttekintése és erről a Bizottság számára jelentés készítése a hatóságok feladata. Mindazonáltal a tagállamok kötelesek lehettek a szabályozásuk megváltoztatására, ha a felülvizsgálat nem igazolható korlátozásokat tárt fel. Ám a tagállamok hatáskörében maradt annak eldöntése, hogy ilyen esetben megszüntetik az adott korlátozást, vagy megfelelően módosítják. A cikk szövegezéséből az Európai Bíróság arra következtetett, hogy az csupán azokat a kereteket határozza meg, amelyeken belül kell maradnia a tagállamoknak a kölcsönzött munkavállalók igénybevételére vonatkozó korlátozásokkal

42 Mt. 216. § (1) bekezdés c) pont.

43 A munkaügyi ellenőrzésről szóló 1996. évi LXXV. törvény (a továbbiakban: Met.) 3. § (1) bekezdés k) pont.

44 Met. 1. $\S(5)$.

45 C-533/13. sz., Auto- ja Kuljetusalan Työntekijäliitto AKT ry kontra Öljytuote ry és Shell Aviation Finland Oy ügyben 2015. március 17-én hozott ítélet (ECLI:EU:C:2015:173). 
vagy tilalmakkal, de amely nem írja elő meghatározott szabályozás elfogadását e téren. Így összességében a nemzeti bíróságok számára sem fakad ebből olyan kötelezettség, hogy ne alkalmazzanak a kölcsönzött munkavállalók igénybevételére vonatkozó olyan korlátozó nemzeti rendelkezést, amelyet nem igazol az irányelv által megkövetelt általános érdek. ${ }^{46}$ Így a hazai korlátozások uniós jogba ütközése csak a Bizottság által indított kötelezettségszegési eljárásokban vizsgálható. Arra azonban nincs lehetőség, hogy magánfelek jogvitájában a kérdést a hazai bíróság az Európai Bírósághoz utalja, illetve a magyar bíróságnak - legyen az uniós jogba ütközés mégoly nyilvánvaló is - kötelessége alkalmazni az uniós joggal ellentétes magyar korlátozást is.

Álláspontom szerint az igen rugalmas magyar szabályozás mellett a kölcsönzésre vonatkozó hazai korlátozások közül csupán kettő esetében merülhet fel kétség, hogy az irányelv által megkövetelt általános érdekkel igazolhatóak-e. ${ }^{47}$

Egyrészt, a magyar jog szerint a közszférában korlátozott a kölcsönzött munkaerő igénybevétele. A közigazgatásban erre nem kerülhet sor, legfeljebb a közigazgatási munkavállalók vonatkozásában. E személyekre a szabályozás speciális szabályokat rögzít, ám azt kifejezetten nem követeli meg, hogy munkaviszonyuk közvetlenül a közigazgatási szervvel álljon fenn. ${ }^{48} \mathrm{~A}$ közalkalmazotti törvény hatálya alatt álló munkáltatónál munkaerő-kölcsönzés csak a munkáltató alaptevékenysége körén kívül lehetséges. Az alaptevékenység körében kölcsönzésre csak abban a kivételes esetben van mód, ha az alaptevékenység szerinti feladat ellátása más módon nem biztosítható. Ez utóbbi azt jelenti, hogy a munkakör haladéktalan betöltése a tevékenység folyamatos ellátásának biztonságos megszervezéséhez elengedhetetlenül szükséges, és az ehhez szükséges személyi feltételek más munkaszervezési eszközökkel nem biztosíthatók. ${ }^{49}$ A közszférára vonatkozó korlátozások további enyhítése célszerü lehet, azzal, hogy a közhatalom gyakorlásával járó munkakörökben - tekintettel a közszolgálatban érvényesülő szigorú kiválasztási és alkalmazási feltételekre - indokolt fenntartani a tilalmat. Egyszersmind a Kjt. is kiegészíthető lenne azzal, hogy a kölcsönzött munkavállaló milyen időtartamban dolgozhat a költségvetési szervnél. ${ }^{50}$

Másrészt, nem lehet a munkavállalót kölcsönözni munkaviszonyra vonatkozó szabály által meghatározott esetben. ${ }^{51}$ Ez a rendelkezés felhatalmazza a kollektív meg-

46 C-533/13. sz., AKT-ügyben hozott ítélet, 28-32. pont. Részletesen lásd: KÁRTYÁs Gábor: A korlátozások felülvizsgálatának megszorító értelmezése. Az Európai Bíróság első ítélete a munkaerő-kölcsönzési irányelvről. Magyar Munkajog E-folyóirat, hll.hu, 2016/1.

47 A magyar jog szerinti tilalmak és korlátozások összefoglalását lásd: CsÉfFÁN József: A Munka Törvénykönyve és magyarázata. Szegedi Rendezvényszervező Kft., Szeged, 2016, 615-616.; NÁDAS György-RAB Henriett-SIPKA Péter-ZACCARIA Márton: A munka törvénykönyvéröl szóló 2012. évi l. törvény kommentárja. Opten Kiadó, Budapest, 2016, 508-509.

48 A közszolgálati tisztviselőkről szóló 2011. évi CXCIX. törvény (a továbbiakban: Kttv.) csak „közigazgatási szervnél foglalkoztatott munkavállalókról” szól, akik így akár kölcsönzöttek is lehetnek [Kttv. 3. § (7), 258. §]. Lásd még a kormányzati igazgatásról szóló 2018. évi CXXV. törvény (a továbbiakban: Kit.) 1. § (2) bekezdését és 278-279. §-át.

49 A közalkalmazottak jogállásáról szóló 1992. évi XXXIII. törvény (a továbbiakban: Kjt.) 3. § (3).

50 HORVÁTH (2015): i. m., 174.

51 Mt. 216. $§(1)$ bekezdés a) pont. 
állapodást kötő feleket, hogy a jogszabályok rendelkezésein túlmenően is tilalmakat határozzanak meg a kölcsönzött munkaerő igénybevételére. Megítélésem szerint ez a szabály azt az elavult szemléletet tükrözi, amely alapján a kölcsönvevőnél müködő munkavállalói érdekképviseletek abban érdekeltek, hogy a kollektív megállapodás korlátozza a kölcsönzött munkaerő igénybevételének lehetőségét. Ezzel szemben - tekintettel elsősorban a munkaerő-kölcsönzés terjedésére - a kölcsönzöttek érdekvédelmének felkarolása lehet életképes szakszervezeti stratégia. Másfelöl, a korlátozások lebontására vonatkozó irányelvi célkitűzéssel ellentétes lehet az a felhatalmazás, hogy a felek kollektív megállapodásokban tetszésük szerint korlátozzák a kölcsönzés igénybevételét. Az irányelv alapján erre csak akkor kerülhet sor, ha a tilalom valamilyen általános érdeket (például a munkavállalók védelmét vagy a viszszaélések elkerülését) szolgálja. Véleményem szerint ezt a felhatalmazást célszerü lenne hatályon kívül helyezni.

\section{A kölcsönzött munkavállaló egyenlő bánásmódhoz való joga}

Az irányelv a kölcsönvevőhöz kikölcsönzött és az általa közvetlenül alkalmazott munkavállaló közötti egyenlő bánásmódot a kikölcsönzés első napjától megköveteli. ${ }^{52}$ Így ha mindketten ugyanazt a teljesítést nyújtják, más szavakkal, ha a két munkavállaló munkaköre, végzettsége, felelössége, tapasztalata stb. alapján összehasonlítható helyzetben van, akkor lényegében csak foglalkoztatásuk jogi konstrukciójában különböznek, ami viszont nem indokol eltérő bánásmódot.

A kölcsönvevő összehasonlítható munkavállalójának meghatározásához az irányelv egy fikcióval él. Eszerint a kölcsönzött munkavállalók alapvető munka- és foglalkoztatási feltételeinek a kölcsönvevőnél való kikölcsönzés időtartama alatt legalább olyan szintűnek kell lenniük, mintha a kölcsönvevő közvetlenül alkalmazta volna őket ugyanarra a munkakörre. ${ }^{53} \mathrm{Az}$ Mt. ennek megfelelöen rögzíti, hogy a kikölcsönzés tartama alatt a munkavállaló számára biztosítani kell a kölcsönvevővel munkaviszonyban álló munkavállalókra irányadó alapvető munka- és foglalkoztatási feltételeket. ${ }^{54}$

Ugyanakkor, az irányelv szerint a kölcsönzött munkavállaló csak azon szempontokból jogosult egyenlő bánásmódra, amelyeket „alapvető munka- és foglalkoztatási feltételként" felsorol. Az irányelv szerint az alapvető munka- és foglalkoztatási feltételek körébe tartoznak a munkaidő hossza, a túlmunka, a szünetek, a pihenőidő, az éjszakai munka, a szabadságok és munkaszüneti napok, valamint a fizetés. ${ }^{55}$ Az irányelv emellett az állapotos nők és szoptató anyák védelmére, továbbá a gyermekek és fiatalok védelmére, valamint a diszkrimináció tilalmára vonatkozó, a kölcsönvevőnél hatályos rendelkezéseket is alkalmazni rendeli a kölcsönzött munka-

52 Irányelv 5. cikk (1).

53 Irányelv 5. cikk (1).

54 Mt. 219. § (1).

55 Irányelv 3. cikk (1) bekezdés f) pont. 
vállalókra. ${ }^{56} \mathrm{Az}$ Mt. az egyenlöséget ennek megfelelő tárgykörben írja elö. ${ }^{57}$ Annak nincs jelentősége, hogy az adott munkafeltételt jogszabály, kollektív szerződés, más munkaviszonyra vonatkozó szabály vagy egyoldalú munkáltatói nyilatkozat (például szabályzat) rögzíti-e, az egyenlő bánásmódot minden esetben biztosítani kell.

Az Mt. felsorolásánál láthatóan hiányoznak a munkaidővel kapcsolatos munkafeltételek. Ennek indoka az lehet, hogy a törvény másutt kimondja, hogy a kikölcsönzés alatt munkaidővel és pihenőidővel, ezek nyilvántartásával kapcsolatos, a munkáltatót megillető jogokat és terhelő kötelezettségeket a kölcsönvevő gyakorolja és teljesíti. ${ }^{58}$ Álláspontom szerint azonban ebböl nem következik, hogy a munkavállaló e területeken automatikusan a kölcsönvevőnél hatályos általános rendelkezések hatálya alá kerülne. Például egyértelmű ebből a szabályból, hogy a szabadságot a kölcsönvevő adja ki a munkavállalónak. Ugyanakkor, ha a kölcsönvevő kollektív szerződése a törvényihez képest több szabadságot biztosít, e szabályt miért kellene alkalmazni a kölcsönzött munkavállalóra is? A kollektív szerződés hatálya ugyanis csak a munkáltatóval munkaviszonyban állókra terjed ki, a kölcsönzöttek pedig nem tartoznak ebbe a körbe..$^{59} \mathrm{Az}$ idézett szabály pedig csak a munkáltatói jogkörről rendelkezik, és nem a kollektív szerződés hatályát határozza meg. Az irányelv-konform értelmezés azzal oldható meg, hogy az Mt. az alapvető munka- és foglalkoztatási feltételek körébe tartozó elemeket a „különösen” szó szerepeltetésével sorolja fel. A lista tehát nyitott, ${ }^{60}$ így abba - az irányelvböl eredően - bele kell értenünk a munkaidővel kapcsolatos kérdéseket is. ${ }^{61}$ Ugyanakkor, nemcsak az irányelvnek való megfelelés, de a gyakorlat szempontjából is kívánatos lenne, hogy az Mt. egyértelműen rögzítse: a munkaidővel összefüggő kérdések is alapvető munka- és foglalkoztatási feltételnek minősülnek. ${ }^{62}$

Végül, a kölcsönzött munkavállaló egyenlő bánásmódhoz való jogának kibővítését jelenti az a szabály, amely szerint a kölcsönzött munkavállalók számára a kölcsönvevő szolgáltatásaihoz, illetve közös létesítményeihez (például az étkezdéhez, a gyermekgondozási létesítményekhez és az utazási szolgáltatásokhoz) a kölcsönvevő saját munkavállalóival megegyező hozzáférést kell biztosítani, kivéve, ha az eltérő bánásmódot objektív indokok támasztják alá. Úgyszintén elő kell segíteni, hogy a kölcsönzöttek részt vehessenek a kölcsönvevőnél biztosított képzésekben. ${ }^{63}$ A kölcsönvevő e szolgáltatásainak elérhetöségét garanciális jelleggel nem mondja ki a magyar szabályozás. ${ }^{64}$ Ez feloldható azzal az értelmezéssel, hogy ezeket a szolgál-

56 Irányelv 5. cikk (1).

57 Mt. 219. § (1)-(2).

58 Mt. 218. $\S(4)$ bekezdés $c)$ pont.

59 Mt. 279. § (3).

60 CSÉFFÁN: i. m., 620.

61 TAKÁCs: i. m., 303.

62 Nem közömbös például, hogy a kölcsönvevő - a kölcsönzött munkavállalók vonatkozásában - alkalmazhat-e hat hónapnál hosszabb munkaidőkeretet, vagy - önként vállalt túlmunkára irányuló megállapodás hiányában - elrendelhet-e évente 250 óránál több rendkívüli munkaidőt, ezen intézkedésekre ugyanis csak kollektív szerződés alapján van mód. Mt. 94. § (3) és 109. § (2).

63 Irányelv 6. cikk (4)-(5).

${ }^{64}$ Ez különösen a kölcsönvevői képzések tekintetében kifogásolható, foglalkoztatáspolitikai szempontból. PRUGBERGER Tamás: A munkavállaló szerződéstől eltérő foglalkoztatása, a posting és a munkaerő-kölcsönzés. Magyar Jog, 2016/4, 216. 
tatásokat (például sportnap) bele kell érteni a tágan értelmezett dijazás fogalmába. ${ }^{65}$ Az is megoldás lehet, hogy a kölcsönzött munkavállalói státuszt az Egyenlö Bánásmód Hatóság elfogadja olyan „egyéb helyzetnek”, amely alapján tilos a hátrányos megkülönböztetés ${ }^{66}$ Így önmagában a kölcsönzésen keresztüli foglalkoztatás miatt e külön nem nevesített munkafeltételek tekintetében sem érhet egy munkavállalót hátrány. Nem tiltja az irányelv, hogy a kölcsönvevő az általa nyújtott szolgáltatások árát beszámítsa a kölcsönzési díjba. A magyar Mt. is megengedi, hogy a kölcsönbeadó és a kölcsönvevő megállapodása alapján, a munkabéren kívüli juttatást a munkavállaló közvetlenül a kölcsönvevőtöl kapja. ${ }^{67}$

Összességében tehát az Mt. általános szabályként a kölcsönzött és közvetlenül alkalmazott munkavállalók közötti egyenlőséget követeli meg. Más kérdés, hogy a kivételek széles köre miatt ez nem feltétlenül érvényesül a gyakorlatban.

\subsection{Kivételek az egyenlő bánásmód alól}

Az egyenlő bánásmód - különösen az egyenlő bér - elvével kapcsolatos viták miatt az irányelv három lehetséges kivételt tartalmaz. ${ }^{68} \mathrm{~A}$ szabályozás kijátszására irányuló magatartások elkerülése érdekében azonban az irányelv kötelezi a tagállamokat, hogy megfelelő intézkedéseket hozzanak az egyenlő bánásmóddal kapcsolatos visszaélések megakadályozására, és ezekröl tájékoztassák a Bizottságot. ${ }^{69}$ Így a kivételeket alkalmazó tagállamnak egyben arra is megfelelő szabályokat kell alkotnia, hogy az adott kivételt ne lehessen indokolatlanul tágan alkalmazni.

Az első lehetséges kivétel szerint a fizetés tekintetében a tagállamok - a szociális partnerekkel folytatott konzultációt követően - mentességet biztosíthatnak az egyenlő bánásmód elve alól olyan esetekben, amikor a kölcsönbeadóval kötött tartós munkaszerződéssel rendelkező kölcsönzött munkavállaló a kikölcsönzések közötti időszakokban is kap fizetést. ${ }^{70} \mathrm{~A}$ két konjunktív feltétel fennállását tehát olyan objektív oknak tekinti az irányelv, amely alapján kivétel tehető az egyenlő bér elve alól. Ezzel lényegében elismeri azt az érvet, hogy az e két jellemzővel bíró, kölcsönzött munkavállaló nem hasonlítható össze a kölcsönvevő közvetlenül alkalmazott munkavállalójával. Más kérdés, hogy e két feltétel rendkívül nehezen értelmezhető. Amint arra Horváth István rámutat, a tartósság csak feltételezhető, miután mindezt a munkaszerződés megkötését követően számos körülmény befolyásolhatja. ${ }^{71}$ Arról

65 Kozma Anna: A több munkáltatóval fennálló munkaviszony. In: Kardkovács Kolos (szerk.): A Munka Törvénykönyvének magyarázata. Budapest, HVG-ORAC, 2012, 400.

66 ZACCARIA Márton Leó: Az egyenlő bánásmód elvének érvényesülése a munkajog területén a magyar joggyakorlatban. Budapest, HVG-ORAC, 2015, 100.

67 Mt. 217. § (2).

68 Ezek közül az egyik csak azokban a tagállamokban érvényesíthető, ahol nincs a kollektív szerződések általánosan alkalmazandóvá nyilvánítására mechanizmus. Mivel a magyar jogban ez létezik, ez a derogációs lehetőség a magyar jog szempontjából érdektelen. Irányelv 5. cikk (4); az ágazati párbeszéd bizottságokról és a középszintű szociális párbeszéd egyes kérdéseiről szóló 2009. évi LXXIV. törvény 17-18. §.

69 Irányelv 5. cikk (5).

70 Irányelv 5. cikk (2).

71 HORVÁTH (2019): i. m., 13. 
pedig egyáltalán nem rendelkezik az irányelv, milyen mértékủ díjazás járjon a két kikölcsönzés között.

Ezzel a kivétellel a magyar jogalkotó is élt. Eszerint a munkabér összegére, az egyéb juttatásokra, az egyenlő bánásmód követelményére vonatkozó rendelkezéseket csak a kölcsönvevőnél történő foglalkoztatás 184. napjától kell alkalmazni arra a munkavállalóra, aki a kölcsönbeadóval munkaerő-kölcsönzés céljából létesített határozatlan idejü munkaviszonyban áll, és kölcsönvevőnél történő foglalkoztatás hiányában is díjazásban részesül. ${ }^{72}$ Mindkét feltétel alapvetően attól függ, hogy a kölcsönbeadó milyen munkaszerződést köt a munkavállalóval. A köztes időre fizethető juttatás mértékére ugyanakkor törvényi minimum nincs, a hatályos szabályozás alapján ráadásul ez az időszak nem is tekinthető álásidőnek. Az Mt. ugyanis csak azt tekinti állásidőnek, amikor a beosztás szerinti munkaidejében nem dolgozik a munkavállaló. Mivel két kikölcsönzés között nincs szó beosztás szerinti munkaidöről, azt nem is lehet állásidőnek tekinteni. ${ }^{73}$ Egy esetben a Kúria átlépett ezen a tételes jogi problémán, és a kikölcsönzés nélküli időszakot - az ennek éppen ellentmondó törvényhelyre hivatkozással - állásidőnek minősítette. ${ }^{74} \mathrm{~A}$ helyzet ugyanakkor csak a szabályozás pontosításával lenne rendezhető. Álláspontom szerint a munkáltatót (itt: a kölcsönbeadót) terhelő foglalkoztatási kötelezettségből eredő világos követelmény, hogy az állásidő tételes jogi fogalma a kikölcsönzések közötti időszakot is felölelje.

Ugyanakkor a tartós foglalkoztatás és a kikölcsönzések közötti időre járó juttatás jelentette komparatív előny könnyen elveszhet. llyen eset, ha a munkavállalót a határozatlan idejü szerződés ellenére rövid idő elteltével elbocsátják, vagy ha a kikölcsönzések között csak jelképes díjazásban részesül, illetve munkaviszonya fennállása alatt nem is lesz ilyen üresjárat, mert a kikölcsönzések megszakítás nélkül követik egymást. Sajnálatos, hogy ilyen esetekre az Mt. nem ad valamilyen utólagos kompenzációt a munkavállaló számára, bár ezt maga az irányelv is kifejezetten megkövetelné. ${ }^{75}$

A második, magyar szempontból releváns kivétel módot ad arra, hogy az adott tagállamban az egyenlő bánásmód kérdését kollektív megállapodásban rendezzék. Eszerint a tagállamok a megfelelő szintű szociális partnerekkel történt konzultációt követően lehetővé tehetik, hogy azok olyan kollektív szerződéseket kössenek vagy tartsanak fenn, amelyek eltérnek az egyenlő bánásmód (nem csak az egyenlő bér) alapelvétöl, feltéve, hogy a kölcsönzött munkavállalók általános védelmét tiszteletben tartják. ${ }^{76} \mathrm{Az}$ irányelv nem határozza meg, mit kell az „általános védelem tiszteletben tartása" alatt érteni. A Bizottság mindenesetre hangsúlyozta, hogy a kivétel helyes értelmezése szerint a kollektív szerződések nem írhatnak elő az egyenlő bánásmód alapján megkövetelt bérnél alacsonyabb díjazást, csak akkor, ha más elöírásokkal ezért megfelelően kompenzálják a kölcsönzött munkavállalókat (például a

72 Mt. 219. $\S(3)$ bekezdés a) pont.

73 Mt. 146. § (1); BERKE-KISS: i. m., 532.; TAKÁcs: i. m., 304.

74 TÁLNÉ MoLnÁR Erika: Kúriai döntések - régi és új elvek. HR\&Munkajog, 2015/5, 18.

75 Irányelv 5. cikk (5).

76 Irányelv 5. cikk (3). 
kikölcsönzések közötti képzések szervezésével). ${ }^{77} \mathrm{~A}$ Bizottság azt is hangsúlyozta, szigorúan ellenőrizni fogja, hogy a gyakorlatban teljesül-e ez a feltétel a kivétellel élő tagállamokban. ${ }^{78}$

Az Mt. szerint a kollektív szerződés az egyenlő bér elvének föszabályától a munkavállaló hátrányára is eltérhet. ${ }^{79} \mathrm{~A}$ kollektív szerződést kötő felek tehát további korlátokat állíthatnak az egyenlő bér elve érvényesülése elé. Ebben a 184 napos szabály sem köti őket, tehát ennél hosszabb időre is félretehető az egyenlő bérezés. Biztosítani kell azonban a „kölcsönzött munkavállalók általános védelmét”.

Azaz, csak megfelelő kompenzáció mellett lehet eltekinteni az elv alkalmazásától. Nem teljesen precíz tehát e ponton a magyar jogharmonizáció, hiszen ez a megkötés az Mt.-böl hiányzik.

Az Mt. további kivételeket is tartalmaz az egyenlö bér elve alól, amelyek az irányelv hatályára vonatkozó rendelkezéseken alapulnak. Az irányelvet ugyanis a tagállam döntése alapján nem kell alkalmazni az állami vagy államilag támogatott szakképzések, beilleszkedési vagy átképzési programok keretében kötött munkaszerződésekre vagy munkaviszonyokra. ${ }^{80}$ Így az Mt. alapján az első 183 napban mentesül a kölcsönbeadó az egyenlő bér elvének betartása alól, ha a munkavállaló a munkaerőpiactól tartósan távol lévő munkavállalónak minősül. ${ }^{81} \mathrm{E}$ személyek foglalkoztatásához különböző járulékkedvezmények társulnak, így esetükben olyan államilag támogatott beilleszkedési programokról van szó, amelyekre tekintettel el lehet tekinteni az irányelv szabályainak alkalmazásától. ${ }^{82}$

Egy további hazai kivétel arra az esetre vonatkozik, ha a kölcsönvevő helyi önkormányzat többségi tulajdonában lévő gazdasági társaság vagy közhasznú szervezet vagy nyilvántartásba vett közhasznú szervezet. ${ }^{83} \mathrm{~A}$ jogalkotó szándéka feltehetően az volt, hogy a nonprofit kölcsönvevőknek nyújtson kedvezményt. Észre kell azonban venni, hogy pusztán ezen az alapon az irányelv szabályait nem lehet félretenni, mivel az csak a gazdasági tevékenységet nem végző szervezeteket zárja ki a hatálya alól, ami nem azonos a nonprofit státusszal. ${ }^{84}$ Kifejezetten kimondja az irányelv, hogy hatálya attól függetlenül kiterjed a munkaerőt kölcsönző vállalkozásokra, hogy nyereségérdekeltek-e. ${ }^{85}$ Másfelöl, azt sem állithatjuk, hogy a helyi önkormányzat többségi tulajdonában álló gazdasági társaság szükségképpen nonprofit tevékenységet folytatna. Végül, e kölcsönvevők tevékenységéhez nem kapcsolódik olyan

77 Ugyanezt az értelmezést követte az ETUI is. Lásd WARNECK, Wiebke: Temporary Agency Work - Guide for Transposition at National Level. European Trade Union Institute, Report 117, 2011, 24.

78 Report from the Commission to the European Parliament, the Council, the European Economic and Social Committee and the Committee of the Regions on the application of Directive 2008/104/EC on temporary agency work, COM(2014) 176 final (a továbbiakban: Implementációs jelentés), 8.

79 Mt. 222. §.

80 Irányelv 1. cikk (3).

81 2004. évi CXXIII. törvény 1. § (2) bekezdés 1. pont, Mt. 219. § (3) bekezdés b) pont.

82 Horváth István ugyanakkor alappal jegyzi meg, hogy a kivétel alkalmazása aligha lehetséges olyan esetben, amikor az érintett munkavállalók valójában nyereségérdekelt kölcsönvevőnél dolgoznak. HoRVÁTH (2015): i. m., 179.

83 Mt. 219. § (3) bekezdés c) pont.

84 HORVÁTH (2019): i. m., 14.

85 Irányelv 1. cikk (1). 
államilag támogatott munkaerőpiaci program sem, amire az egyenlő bér elve alóli kivételt alapozni lehetne. Ezért megítélésem szerint e kivételnek semmilyen irányelvi alapja nincs. Ráadásul - a kifejtettek alapján - az sem érthető, miért pont ezeket a kölcsönvevőket kívánta előnyben részesíteni a jogalkotó.

Az első naptól alkalmazandó egyenlő bánásmód elve kétségtelenül mérföldkő a munkaerő-kölcsönzés, illetve az egyenlő bér elve történetében. Az elvi jelentőségü szabály azonban igen megengedő. A kivételek köre és rugalmas megfogalmazása mellett egyrészt igen különböző előírások maradnak majd hatályban az egyes nemzeti jogrendszerekben, másrészt nagy valószínűséggel a kölcsönzött munkavállalók széles köre az egyenlő bér elvének hatályán kívül marad. További probléma, hogy a kivételek olyan tényállásokhoz igazodnak, amelyek nem indokolják a kölcsönzött munkaerő hátrányosabb bérezését.

\section{A munkaviszony megszüntetésének speciális szabályai}

A munkaviszony megszüntetésére vonatkozóan jogharmonizáció ez idáig nem történt, mégis van néhány olyan uniós elöírás, amit tiszteletben kell tartani a kölcsönzésre irányuló munkaviszony megszüntetésére vonatkozó hazai szabályok kialakításánál.

Az első probléma, hogy az Mt. szerint a munkaerő-kölcsönzés esetén a csoportos létszámcsökkentés szabályait nem kell alkalmazni. ${ }^{86}$ A kölcsönzési tevékenységből, illetve a kölcsönbeadó korlátozott, a kölcsönvevő által behatárolt munkáltatói mozgásteréből eredően gyakori, hogy a kölcsönbeadónak egyszerre nagy létszámú munkavállalót kell elbocsátania. Ezek a leépítések tehát nem rendkívüliek, hanem a rendes üzletmenet részét jelentik, így a csoportos létszámcsökkentés szabályaival járó adminisztratív terhek igen jelentősek lennének. Másfelöl, mivel a kölcsönvevő rövid határidővel, akár azonnali hatállyal is visszaküldhet nagy létszámú munkavállalót, a munkavállalók leépítéséről való előzetes tájékoztatására vonatkozó szabály betartása gyakorlatilag lehetetlen volna. Ehhez képest sajnálatos, hogy a csoportos létszámcsökkentésről szóló 98/59/EK irányelv hatálya a munkaerő-kölcsönzésre is kiterjed, így az egyébként észszerü magyar szabály nem egyeztethető össze az uniós joggal. ${ }^{87}$

A felmondás indokolása tekintetében az Mt. drámai változást hozott, előírva, hogy a felmondás indokolása tekintetében a kölcsönbeadó működésével összefüggő oknak minősül a kikölcsönzés megszűnése is. ${ }^{88}$ Azaz, a kölcsönbeadó a kikölcsönzés megszűnésével nyomban felmondást közölhet a munkavállalóval, egyszerüen e tényre hivatkozva. Így a gyakorlatban a kikölcsönzés vége legtöbbször a munkaviszony végét is jelentheti, ami a munkavállalók számára igen előnytelen. Észre kell venni, hogy ilyen esetben a felmondás indoka egyszerüen az, hogy a munkavállaló kikölcsönzése megszünt. ${ }^{89}$ Arra már nem kell kitérni a felmondás indokolásában,

${ }_{86}$ Mt. 222. § (4).

87 BERKE-KISS: i. m., 626.

88 Mt. 220. § (1).

89 Éppen ezért viszont nem fogadható el jogszerủ indoknak, ha a kikölcsönzés csak a felmondás közlését követően (pl. a felmondási idő lejártakor) fog megszünni. KozmA: i. m., 402-403. 
hogy miért ért véget a kikölcsönzés (például mert a kölcsönvevőnél kisebb létszámú munkaerő vált szükségessé, vagy a munkavállaló rosszul teljesített, kötelezettségszegést követett el). Így a munkavállaló nem tudja vitatni a felmondás jogszerüségét, hiszen a kikölcsönzés megszünése - a törvény ereje által - önmagában okszerü indoka a munkaviszony megszüntetésének. Ráadásul, a kikölcsönzés megszüntetését a kölcsönvevőnek a törvény szerint egyáltalán nem kell indokolnia, ${ }^{00}$ illetve azt olyan körülmény is kiválthatja, amelyet maga a kölcsönbeadó is előidézhet (például adott munkavállaló visszahívásával és egyidejű helyettesítésével, vagy a kölcsönvevővel kötött szerződés felmondásával). A munkavállalót még arról sem kell tájékoztatni, hogy a kölcsönvevő vagy a kölcsönbeadó szüntette-e meg a kikölcsönzést. ${ }^{91}$

$\mathrm{Az}$ indokolással kapcsolatos aggályokat jól mutatja egy konkrét eset, amelyben a munkavállaló kikölcsönzését azt követően szüntette meg a kölcsönvevő, hogy a müszak végén távozáskor egy munkavédelmi kesztyüt találtak nála. A kölcsönbeadó felmondásának indoka a kikölcsönzés megszünése volt, így a munkavállaló hiába vitatta a perben, hogy ő a kesztyüt el akarta volna tulajdonítani. A bíróság szerint azt a körülményt, hogy a kölcsönvevő milyen indokkal szünteti meg a kikölcsönzést, a bíróság nem vizsgálhatja. Mivel pedig a kikölcsönzés ténylegesen megszűnt, a felmondás indokolása jogszerü. Ehhez képest a felmondás jogellenességét legfeljebb rendeltetésellenes joggyakorlás vagy diszkrimináció esetén lehetne megállapítani. ${ }^{92}$

Megítélésem szerint a kikölcsönzés megszűnésének felmondási indokként való elfogadása lényegében indokolás nélküli munkáltatói felmondást jelent. Ez világosan szembemegy az Európai Unió Alapjogi Chartájának 30. cikkével, ami biztosítja, hogy minden munkavállalónak joga van az indokolatlan elbocsátással szembeni védelemhez. A Charta azonban csak az uniós jog végrehajtása körében köti a tagállamokat, ${ }^{93}$ márpedig - mint említést nyert - jelenleg nincs olyan uniós irányelv, ami a munkaviszony megszüntetését szabályozná. Ezért a Charta korlátozott hatálya ezt a rendelkezést kiüresíti. ${ }^{94}$ Ugyanakkor érdemes e ponton párhuzamot vonni a kormánytisztviselök, köztisztviselök indokolás nélküli felmentésére vonatkozó korábbi szabályokkal. Az Alkotmánybíróság 2011-ben több ponton alkotmányellenesnek találta, hogy a kormánytisztviselőket általában, a köztisztviselőket pedig bizonyos esetekben a munkáltató indokolás nélkül felmenthette. ${ }^{95} \mathrm{Az}$ itt kifejtett alkotmányos aggályok meglátásom szerint irányadóak a munkaerő-kölcsönzésre irányuló munkaviszony felmondásának jelenlegi szabályozása kapcsán is. ${ }^{96}$

90 PRUGBeRger Tamás: Jogdogmatikai, gazdasági és szociálpolitikai összefüggések egyes munka- és gazdaságjogi intézmények között. Magyar Jog, 2003/10, 582-583.

91 TAKÁCS: i. m., 306.

92 4.M.503/2013/9. Részletesen lásd Kovács Szabolcs: A kikölcsönzés megszünése mint felmondási indok egy bírósági ítélet tükrében. HR\&Munkajog, 2014/5, 27-28.

${ }_{93}$ Alapjogi Charta 51. cikk (1).

94 KENNER, Jeff: Article 30: Protection in the Event of Unjustified Dismissal. In: The EU Charter of Fundamental Rights: A Commentary. Hart Publishing, Oxford, 2014, 4. (https://doi.org/10.5771/9783845259055_848); Kovács Erika: Individual Dismissal Law and the Financial Crisis: an Evaluation of Recent Developments. European Labour Law Journal, 2016/3, 384-385. (https://doi.org/10.1177/201395251600700304).

95 8/2011. (II. 18.) AB határozat, $A B H$ 2011, 49; 29/2011. (IV. 7.) AB határozat, ABH 2011, 181.

96 Hasonló következtetésre jut PETRovics Zoltán: A biztonság árnyékában. A munkajogviszony megszüntetésével szembeni védelem alapkérdései. PhD-értekezés, Budapest, 2016, 294. 
Az Alkotmánybíróság ugyanis kimondta, hogy az egyoldalú munkáltatói megszüntetés esetén az indokolási kötelezettség törvényi szabályozása olyan garanciális kérdés, amely alkotmányos jelentőséggel bír, és amelynek szabályozása a munkához való joggal összefüggésben az állam intézményvédelmi kötelezettsége körébe tartozik. ${ }^{97} \mathrm{~A}$ munkához való jogot sérti tehát, ha az alárendeltségben történő munkavégzésre irányuló munkaviszonyt a munkáltató indokolás nélkül szüntetheti meg egyoldalúan. Az Alkotmánybíróság következő érve szerint, indokolás hiányában nincs hatékony jogvédelem a munkáltatói döntéssel szemben. Bár azt bíróság előtt meg lehet támadni, az indokolás mellőzése aránytalanul korlátozza a munkát végzőt megillető, bírói jogvédelemhez való jogot. ${ }^{98}$ Végül, az indokolás hiánya miatt kiszámíthatatlan módon kerülhet veszélybe a munkát végző és családjának létfenntartása. Mindez feltétlen alárendeltséget, kiszolgáltatott helyzetet teremt számára. Ez a kiszolgáltatott helyzet - az Alkotmánybíróság megfogalmazásában a kormánytisztviselők, köztisztviselők „állami feladatmegoldás eszközeként való kezelése” ellentétes az emberi méltósággal. ${ }^{99}$

Ezeket az aggályokat jól mutatja a fent ismertetett eset. Mivel a kikölcsönzés megszüntetése nem jelent érdemi indokolási kötelezettséget a kölcsönbeadó számára, fel kell vetni a kölcsönzött munkavállalók munkához, hatékony jogvédelemhez való joga, illetve emberi méltósága sérelmének veszélyét.

\section{Kollektív munkajogi kérdések}

Nem kétséges, hogy a kölcsönzött munkavállaló is alárendeltségben, önállótlanul teljesít, ezért szüksége van a kollektív munkajog jelentette védelemre. Azonban az érdemi érdekvédelemhez olyan szabályozásra van szükség, amely figyelembe veszi a megosztott munkáltatói pozícióból eredő sajátosságokat. Az Mt. munkaerőkölcsönzésre vonatkozó fejezete nem tartalmaz eltérő rendelkezéseket a kollektív jogok vonatkozásában, tehát az általános szabályok alkalmazandók. Így elsőre úgy tünhet, hogy a kölcsönzött munkavállaló kollektív munkajogi védelme kifogástalan. A 2008/104/EK irányelv csak azt követeli meg, hogy - a tagállam választása szerint - a kölcsönbeadónál és/vagy a kölcsönvevőnél a kölcsönzött munkavállalókat is be kell számítani az érdekképviseleti szervek létrehozására vonatkozó létszámküszöbökbe. ${ }^{100}$ Valamelyik „munkáltatónál” a magyar szabályok szerint is minden képviseleti forma (szakszervezet, üzemi tanács, munkavédelmi képviselet) esetében figyelembe kell venni a kölcsönzötteket. Más vonatkozásban azonban felmerülnek uniós jogi aggályok a kölcsönzött munkavállalók kollektív jogai kapcsán.

Így kétséges a szakszervezeti tisztségviselőt megillető munkajogi védelem érvényesülése munkaerő-kölcsönzés esetén. $E$ védelem lényege az, hogy az Mt. a szakszervezeti tisztségviselöt - megbízatására tekintettel - különleges védelemben

97 Alkotmány 70/B. § (1); Alaptörvény M) és XII. cikk.

98 Alkotmány 57. § (1); Alaptörvény XXVIII. cikk.

99 Alkotmány 54. § (1); Alaptörvény II. cikk.

100 Irányelv 7. cikk (1)-(3). 
részesíti a munkáltató olyan egyoldalú intézkedéseivel szemben, amelyek kiszakíthatják abból a kollektívából, ahol érdekképviseleti feladatait betölti. Ez abban ölt testet, hogy az ilyen hatású munkáltatói intézkedések a felettes szakszervezeti szerv hozzájárulásához kötöttek. Jelenleg a munkaszerződéstől eltérő foglalkoztatás (átirányítás, kiküldetés, kirendelés) és a felmondás tartozik ebbe a körbe. ${ }^{101}$

A tisztségviselöt megillető védelem munkaerö-kölcsönzés esetén azonban csak úgy lehetne teljes, ha a kölcsönzött szakszervezeti tisztségviselö kikölcsönzésének megszüntetéséhez is szükség lenne a szakszervezet beleegyezésére. A kikölcsönzés megszüntetése azt jelenti, hogy a kölcsönvevő (vagy ritkábban a kölcsönbeadó) intézkedése révén megszűnik a foglalkoztatása az adott kölcsönvevőnél. Ezt követően vagy újabb kölcsönvevőhöz kerül kikölcsönzésre, vagy megszüntetik a munkaviszonyát. Az Mt. egyáltalán nem szabályozza azt a kérdést, hogy a kölcsönvevő mikor és milyen feltételekkel küldheti vissza a kikölcsönzött munkaerőt. Ebből fakadóan, a kölcsönvevő könnyen lehetetlenné teheti a kölcsönzött munkavállalói körében megvalósuló szakszervezeti munkát, ha a tisztségviselőket - akik a szervezet mozgatórugói - egyszerūen visszaküldi a kölcsönbeadónak. E magatartása ellen ugyanis a szakszervezet a munkajogi védelem szabálya alapján nem tehet semmit, bár hatásában ugyanaz, mintha felmondtak volna tisztségviselőinek. Egy ilyen kölcsönvevői intézkedéssel szemben az érintett legfeljebb az egyenlő bánásmód sérelmére vagy joggal való visszaélésre hivatkozhat. ${ }^{102}$ Ám mindkét eset csak hosszadalmas bírósági eljárás után hozhat eredményt, a bizonyítás pedig meglehetösen nehéz volna. A probléma azért fontos, mert a kölcsönzött munkavállalók érdekvédelme a gyakorlatban hatékonyan csak akkor oldható meg, ha a szakszervezet egy tisztviselöje ott van a tényleges munkáltatónál, a kölcsönvevőnél.

Az érdemi védelem nélkül hagyott kölcsönzött tisztségviselök helyzete az uniós jog szempontjából is kifogásolható. Az ún. konzultációs irányelv ugyanis arra kötelezi a tagállamokat, hogy a munkavállalók képviselői megfelelő garanciát kapjanak, amely lehetővé teszi a rájuk ruházott feladatok megfelelő elvégzését. ${ }^{103}$ Kérdéses, hogy a visszaküldés állandó veszélye mellett mennyire lehet érdemi feladatellátásról beszélni az esetükben.

Egy másik, kevésbé jelentős uniós jogi probléma: a 91/383/EGK irányelv úgy rendelkezik, hogy a munkavédelmi képviseletet is tájékoztatni kell a kölcsönzött munkavállalók megbízatásáról, azért, hogy védelmi és megelőzési feladatait a kölcsönvevőnél dolgozó valamennyi munkavállaló érdekében elláthassa. ${ }^{104} \mathrm{~A}$ munkavédelmi törvény tartalmazza a munkáltató tájékoztatási kötelezettségét, amelyet a munkavédelmi képviselő (bizottság) irányában kell teljesítenie, ${ }^{105}$ de ezt nem konkretizálja az irányelvben elöírtak szerint. Sem az Mt., sem az Mvt. nem nevesíti tehát a kölcsön-

101 Mt. 273. §.

102 Mt. 7. § és 12. §.

103 Az Európai Parlament és a Tanács 2002/14/EK irányelve (2002. március 11.) az Európai Közösség munkavállalóinak tájékoztatása és a velük folytatott konzultáció általános keretének létrehozásáról, 7 . cikk.

104 A Tanács 1991. június 25-i 91/383/EGK irányelve a határozott idejű vagy munkaerő-kölcsönzés céljából létesített munkaviszonyban álló munkavállalók munkahelyi biztonságának és egészségének javítását elősegítő intézkedések kiegészítéséről, 6 . cikk.

105 Mvt. 71. §. 
zött munkavállalók alkalmazásáról szóló tájékoztatási kötelezettséget a munkavédelmi képviselet vonatkozásában, amit álláspontom szerint pótolni kell.

\section{Várható jogharmonizációs feladatok}

Bár a kölcsönzési irányelv módosítása egyelöre nincs napirenden, a közelmúltban két új irányelv is hatályba lépett, amelyek érintik a munkaerö-kölcsönzést. Ezek az alábbi jogharmonizációs feladatok elé állítják a magyar jogalkotót.

A határon átnyúló szolgáltatásnyújtás keretében megvalósuló kölcsönzésre az uniós jog speciális szabályokat tartalmaz. A kiküldetési irányelv módosítása ${ }^{106}$ e körben több pontosító rendelkezést vezet be. Egyrészt a jogalkotó rendezi a „továbbküldés” helyzetét. Ebben az esetben a munkavállalót nem a kölcsönbeadó, hanem a kölcsönvevő küldi ki egy másik tagállamba. Az új szabály alapján - a munkavállalók védelme érdekében ${ }^{107}$ - a kiküldetéssel kapcsolatos munkáltatói kötelezettségekért ilyen esetben továbbra is a kölcsönbeadó felelös. ${ }^{108}$ Meg kell jegyezni, hogy mivel a munkaviszony a kölcsönbeadóval áll fenn, ${ }^{109}$ álláspontom szerint ez következett a módosítás elötti szövegböl is. E körben az Mt. módosítása nem szükséges.

Másrészt a módosító irányelv deklarálja, hogy a kiküldött kölcsönzött munkavállaló is jogosult a (külföldi) kölcsönvevő saját munkavállalóival egyenlő bánásmódra, ahogy azt a munkaerö-kölcsönzési irányelv 5. cikke elöírja. Az irányadó munkafeltételekröl a kölcsönvevőnek kötelező tájékoztatást adnia a kölcsönbeadónak. ${ }^{110}$ Véleményem szerint ezt is szükségtelen külön rögzíteni a normaszövegben. A kiküldetési irányelv szerint ugyanis a munkavállalók rendelkezésre bocsátásának (kikölcsönzésének) feltételei ma is a kiküldött munkavállalóra alkalmazandó szabályok között szerepelnek. ${ }^{111}$ Nyilvánvalóan ide tartoznak a kölcsönzési irányelv által megkövetelt, egyenlő bánásmóddal kapcsolatos nemzeti rendelkezések is, valamennyi tagállamban. Mivel az Mt. szerint a kölcsönzésre irányadó valamennyi feltétel vonatkozik a kiküldött kölcsönzöttekre is, ${ }^{112}$ ennek az irányelvi követelménynek jelenleg is megfelel a magyar jog.

A másik új jogalkotási fejlemény a munkaviszony létesítésekor adandó tájékoztatásról szóló irányelv módosítása. Az új jogszabály a munkáltató tájékoztatási kötelezettségét kölcsönzés esetén kiterjeszti a kölcsönvevő vállalkozás megnevezésére

106 2018/957 (EU) irányelv a munkavállalók szolgáltatások nyújtása keretében történő kiküldetéséről szóló 96/71/EK irányelv módosításáról (a továbbiakban: módosító irányelv).

107 Módosító irányelv, Preambulum (13).

108 A kölcsönvevő a kiküldetés előtt köteles kellő időben tájékoztatni a kölcsönbeadót a más tagállambeli munkavégzésről. A módosító irányelvvel megállapított 1. cikk (3) bekezdés 2. albekezdése.

109 Az Európai Parlament és a Tanács 2008/104/EK irányelve (2008. november 19.) a munkaerö-kölcsönzés keretében történő munkavégzésröl 3. cikk (1) bekezdés b) pont; Kiküldetési irányelv 1. cikk (3) bekezdés $c$ ) pont.

110 A módosító irányelvvel megállapított 3. cikk (1b); 2008/104/EK irányelv 5. cikk.

111 Kiküldetési irányelv 3. cikk (1) bekezdés $d$ ) pont.

112 Mt. 295. § (1) bekezdés $d$ ) pont. 
is, amit azonnal közölni kell a munkavállalóval, amint ismertté válik. ${ }^{113}$ Ezt a magyar jog jelenleg is előírja, ${ }^{114}$ egyedül a határidőt szükséges pontosítani, mivel a tájékoztatást az Mt. szerint elegendő a kikölcsönzés kezdetéig teljesíteni.

\section{8. Összegzés}

A munkaerő-kölcsönzésre irányuló munkaviszony szabályai az Mt. hatályba lépése óta érdemben nem változtak, noha a tanulmányban jelzett problémák 2012 óta fennállnak. A szabályozás felülvizsgálatához ezért kézenfekvő szempont, hogy az uniós jogba ütköző előírásokat célszerű minél előbb saját hatáskörében korrigálnia a jogalkotónak, mintsem megvárni, hogy erre a Bizottság által indított kötelezettségszegési eljárásban kerüljön sor. Meglátásom szerint az uniós szempontból problematikus rendelkezések (így különösen az egyenlő bánásmód garanciák nélküli korlátozása) hazai érdekeket sem szolgálnak. A tanulmányban bemutatott jogharmonizációs problémákat a 3 . táblázat összegzi.

3. táblázat. A munkaerö-kölcsönzéssel kapcsolatos jogharmonizációs problémák

\begin{tabular}{|c|c|}
\hline Magyar jog & Uniós jog \\
\hline $\begin{array}{l}\text { A közszférában csak erös korlátok mellett ve- } \\
\text { hető igénybe a munkaerő-kölcsönzés. Emel- } \\
\text { lett az Mt. felhatalmazza a kollektív szerződést } \\
\text { kötő feleket, hogy további korlátozásokat álla- } \\
\text { pítsanak meg a kölcsönzött munkavállalók } \\
\text { igénybevételére. } \\
\text { [Kttv., Kit., Kjt. 3. § (3), Mt. 216. § (1) bekez- } \\
\text { dés a) pont] }\end{array}$ & $\begin{array}{l}\text { A munkaerő-kölcsönzésről szóló irányelv a } \\
\text { korlátozások és tilalmak lebontására hív fel, } \\
\text { amelyek csak akkor tarthatóak fenn, ha álta- } \\
\text { lános érdeket szolgálnak. Ez a jelzett ese- } \\
\text { tekben kétséges. } \\
\text { (2008/104/EK irányelv 4. cikk) }\end{array}$ \\
\hline $\begin{array}{l}\text { Az alapvető munka- és foglalkoztatási felté- } \\
\text { telek között a munkaidő nem szerepel. } \\
\text { [Mt. 219. § (2)] }\end{array}$ & $\begin{array}{l}\text { Az irányelv e körbe sorolja a munkaidővel } \\
\text { kapcsolatos rendelkezéseket is. } \\
\text { [2008/104/EK irányelv } 3 \text {. cikk (1) bekezdés } \\
\text { f) pont] }\end{array}$ \\
\hline $\begin{array}{l}\text { Az egyenlő bánásmódra vonatkozó szabály- } \\
\text { tól kollektív szerződés a munkavállaló hátrá- } \\
\text { nyára is eltérhet. } \\
\text { [Mt. } 222 . \S(1)-(2)]\end{array}$ & $\begin{array}{l}\text { Kollektív szerződés az egyenlő bánásmód } \\
\text { elvétől csak a kölcsönzött munkavállalók ál- } \\
\text { talános védelmének tiszteletben tartása mel- } \\
\text { lett térhet el. } \\
\text { [2008/104/EK irányelv 5. cikk (3)] }\end{array}$ \\
\hline $\begin{array}{l}\text { Kivétel tehető az egyenlő bér elve alól, ha } \\
\text { a kölcsönvevő helyi önkormányzat többségi } \\
\text { tulajdonában lévő gazdasági társaság vagy } \\
\text { közhasznú szervezet vagy nyilvántartásba } \\
\text { vett közhasznú szervezet. } \\
\text { [Mt. } 219 \text {. § (3) bekezdés c) pont] }\end{array}$ & $\begin{array}{l}\text { Ilyen derogációra az uniós jog nem ad lehe- } \\
\text { tőséget. } \\
\text { (2008/104/EK irányelv 1. és 5. cikk) }\end{array}$ \\
\hline
\end{tabular}

113 Az Európai Parlament és a Tanács 2019/1152 (EU) irányelve (2019. június 20.) az Európai Unióban alkalmazandó átlátható és kiszámítható munkafeltételekről 4. cikk (2) bekezdés f) pont.

114 Mt. 218. § (3) bekezdés a) pont. 


\begin{tabular}{|c|c|}
\hline Magyar jog & Uniós jog \\
\hline $\begin{array}{l}\text { A csoportos létszámcsökkentés szabályait } \\
\text { munkaerő-kölcsönzésnél nem kell alkalmazni. } \\
\text { [Mt. 222. § (4)] }\end{array}$ & $\begin{array}{l}\text { llyen kivételt az uniós jog nem tesz lehetővé. } \\
\text { (98/59/EK irányelv) }\end{array}$ \\
\hline $\begin{array}{l}\text { Nem tiltható, hogy a kölcsönvevővel létesít- } \\
\text { sen jogviszonyt a munkavállaló a kikölcsön- } \\
\text { zés után. } \\
\text { [Mt. } 216 . \S(3)]\end{array}$ & $\begin{array}{l}\text { Ha a kölcsönvevő átveszi a kölcsönzött mun- } \\
\text { kavállalókat, az ezért kért átvételi díj csak } \\
\text { észszerü mértékü lehet. Ez a megkötés hiány- } \\
\text { zik a magyar jogból. } \\
\text { [2008/104/EK irányelv 6. cikk (2)] }\end{array}$ \\
\hline $\begin{array}{l}\text { Nincs kifejezett tájékoztatási kötelezettség a } \\
\text { munkavédelmi képviselet irányában a köl- } \\
\text { csönzött munkavállalók alkalmazásáról. } \\
\text { [Mvt. 71. §, Mt. 216. § (4)] }\end{array}$ & $\begin{array}{l}\text { A munkavédelmi képviseletet is tájékoztatni } \\
\text { kell a kölcsönzött munkavállalók igénybevé- } \\
\text { teléről. } \\
(91 / 383 / E G K \text { irányelv } 6 . \text { cikk) }\end{array}$ \\
\hline $\begin{array}{l}\text { A kölcsönzött szakszervezeti tisztségviselők } \\
\text { visszaküldése ellen nincs munkajogi véde- } \\
\text { lem. } \\
\text { (Mt. 273. §) }\end{array}$ & $\begin{array}{l}\text { Megfelelő garanciát kell biztosítani, amely le- } \\
\text { hetővé teszi, hogy a munkavállalók képvise- } \\
\text { lői a rájuk ruházott feladatokat megfelelően } \\
\text { elvégezhessék. } \\
\text { (2002/14/EK irányelv) }\end{array}$ \\
\hline $\begin{array}{l}\text { A kölcsönzési tevékenység folytatásához tá- } \\
\text { masztott feltételrendszer nincs tekintettel a } \\
\text { duplikáció tilalmára. } \\
\text { (Kr.) }\end{array}$ & $\begin{array}{l}\text { A szolgáltatásnyújtás szabadsága nem kor- } \\
\text { látozható olyan előírásokkal, amelyek meg- } \\
\text { akadályozzák, korlátozzák, vagy kevésbé von- } \\
\text { zóvá teszik a szolgáltatási tevékenységet a } \\
\text { más tagállamban letelepedett szolgáltatás- } \\
\text { nyújtók számára. } \\
\text { (Az Európai Unió Működéséről szóló Szerző- } \\
\text { dés 56-62. cikk és a rá épülő bírói gyakorlat) }\end{array}$ \\
\hline $\begin{array}{l}\text { Az iskolaszövetkezeti jogviszony szabályo- } \\
\text { zása nem felel meg a munkaerő-kölcsönzési } \\
\text { irányelvnek. } \\
\text { (A szövetkezetekről szóló 2006. évi X. törvény) }\end{array}$ & $\begin{array}{l}\text { Az iskolaszövetkezeti munkaviszony a mun- } \\
\text { kaerö-kölcsönzési irányelv hatálya alá tarto- } \\
\text { zik. } \\
\text { [2008/104/EK irányelv 1. cikk és 3. cikk (1)] }\end{array}$ \\
\hline
\end{tabular}

Forrás: saját szerkesztés

\begin{abstract}
Temporary agency work was introduced into Hungarian law on the $1^{\text {st }}$ July 2001. After nearly two decades of experience and numerous legislative changes, the domestic regulation of agency work is still not finished or coherent, and it is burdened with a number of EU harmonization shortcomings, constitutional concerns and practical problems. The purpose of this study is to examine the Hungarian legal regulation of temporary agency work from the point of view of EU law, while also highlighting a number of issues of domestic law that needs to be clarified.
\end{abstract}

